\title{
会員寄書
}

\section{吸着等温線が直線てない場合の過渡状態 の解析法*}

杉山幸男**

1. 腥 害

すでに筆者”は吸着等温線が直線の場合についての過 渡状態の解析を行ったが，东際には等温楾が曲線をしめ す場合がなかなか多い。このように等温線が曲線となる 場合の過渡状態の解析は Grossman", Hougen ${ }^{22}$ さら に河添氏3゙らにって報告されているょらに主として図 解法にるとついている。筆者はここで図解法より精度が “たかく，また計算す比較的容易な数值解法をえたので報 告する。

\section{2. 解析方法}

充填層内非定常吸着について考えると

$$
\begin{aligned}
d w & =(\partial w / \partial u)_{v} d u+(\partial w / \partial v)_{u} d v \\
d y & =(\partial y / \partial u)_{v} d u+(\partial y / \partial v)_{u} d v \\
(\partial w / \partial \tau)_{z} & =(\partial w / \partial u)_{v}(\partial u / \partial \tau)_{z}+(\partial w / \partial v)_{u}(\partial v / \partial \tau)_{z}
\end{aligned}
$$$$
(\partial y / \partial z)_{\tau}=(\partial y / \partial u)_{v}(\partial u / \partial z)_{\tau}+(\partial y / \partial v)_{v}(\partial v / \partial z)_{\tau}
$$

$$
(\partial y / \partial \tau)_{z}=(\partial y / \partial u)_{v}(\partial u / \partial \tau)_{z}+(\partial y / \partial v)_{u}(\partial v / \partial \tau)_{z}
$$

ただし $u=\alpha z \quad v=\beta(\tau-\gamma z)$$$
\alpha=1 / H_{d}, \quad \beta=G / \rho_{B} H_{d}, \quad r=\rho_{G} F_{d} / G
$$

(6) より

$$
\begin{aligned}
& (\partial u / \partial z)_{\tau}=\alpha \\
& (\partial u / \partial \tau)_{z}=0 \\
& (\partial v / \partial z)_{\tau}=-\beta \tau \\
& (\partial v / \partial \tau)_{z}=\beta
\end{aligned}
$$

一方充填層内物質収支より

$$
\begin{gathered}
\left(\partial_{w} / \partial_{\tau}\right)=\beta\left(y-y^{*}\right) \\
\left(\partial_{y} / \partial z\right)+\gamma(\partial y / \partial \tau)=-\alpha\left(y-y^{*}\right)
\end{gathered}
$$

Wま, $y / y_{0}=\psi_{1}, y^{*} / y_{0}=\psi_{2}, \quad w / w_{0}=\psi_{3}, \quad v^{\prime}=\left(y_{0} / w_{0}\right) v$ とおき，(11)，(9)，(12)，(3)より

$$
(\partial w / \partial v)=\left(y-y^{*}\right)
$$

あるいは,

$$
\left(\partial \psi_{3} / \partial v^{\prime}\right)=\left(\psi_{1}-\psi_{2}\right)
$$

また，(10)，(11)，(4)，(5)，(8)，(9)，(13)より

\footnotetext{
* 昭和 33 年 9 月 26 日受理
}

** 名古屋大学工学部化学工学科

$$
\begin{aligned}
&(\partial y / \partial u)=-\left(y-y^{*}\right)(15) \\
& \text { あるいは }\left(\partial \psi_{1} / \partial u\right)=-\left(\psi_{1}-\psi_{2}\right)
\end{aligned}
$$
をらる。

さらに吸着等温線が次式で表わせるとすると

$$
\psi_{2}=f\left(\psi_{3}\right)
$$

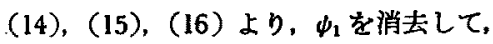
$\partial^{2} \psi_{3} / \partial u \partial v^{\prime}+\partial \psi_{3} / \partial v^{\prime}+\partial \psi_{2} / \partial u=0$

いま,

$$
\psi_{2}=f\left(\phi_{3}\right)=\psi_{3}-f_{1}\left(\psi_{3}\right)
$$

として,

$$
\partial^{2} \psi_{3} / \partial u \partial v^{\prime}+\partial \psi_{3} / \partial v^{\prime}+\partial \psi_{3} / \partial u=\partial f_{1} / \partial u
$$

をらる。

(19) 式の解は

$$
\begin{aligned}
& \psi_{3}(11)-f_{1}(11) / 4 \doteqdot\left\{\psi_{3}(10)+\phi_{3}(01)\right\} \\
&+1 / 4\left\{f_{1}(10)-f_{1}(01)-f_{1}(00)\right\}
\end{aligned}
$$

となる。したがって $\psi_{3}(10) ， \psi_{3}(01)$ などの右辺が既知 ならば $\psi_{3}(11)-f_{1}(11) / 4$ がしれる。しかる $f_{1} \sim \psi_{3}$ の関 係は既知だから $\Psi_{3}(11)$ あるい㤝 $f_{1}(11)$ がしれる。

初期条件は，

$$
\begin{array}{r}
u=0 \text { で } \psi_{1}=1 \quad \begin{array}{r}
\text { か. } \\
\partial \psi_{3} / \partial v=1-\phi_{2} \\
=1-\psi_{3}+f_{1}\left(\psi_{3}\right)
\end{array} \\
v=0 \text { で } \psi_{3}=0
\end{array}
$$

からあとまる。また $\boldsymbol{\psi}_{3}$ の分析がきまれば

$$
\psi_{1}=\partial \psi_{3} / \partial v^{\prime}+\psi_{2}=\partial \psi_{3} / \partial v^{\prime}+\psi_{3}-f_{1}\left(\phi_{3}\right)
$$

で中がるとまる。

\section{3. 結果の榙討}

数値解析結果の 1 例を河添氏の図解法の場合と比較す ると Fig. 3 のことくになる。吸着等温線は Fig. 1, 計 算の基喽になるデータは Table 1, 計算に使用する图を Fig. 2 にしめす。データはすざて河添氏のむのを引用 した。数值解による $\phi_{3}$ の分布曲線は $u \geq 4$ からはたんに "の方にずれるだけである。これより見てかかるようK 両者の結果は割合によい一致をしめしている。

\section{4. 結 論}

吸着等温線が曲線となる場合の過渡状態の解析法は從 米主として，四解法によっていたが，この眓解法は精度 


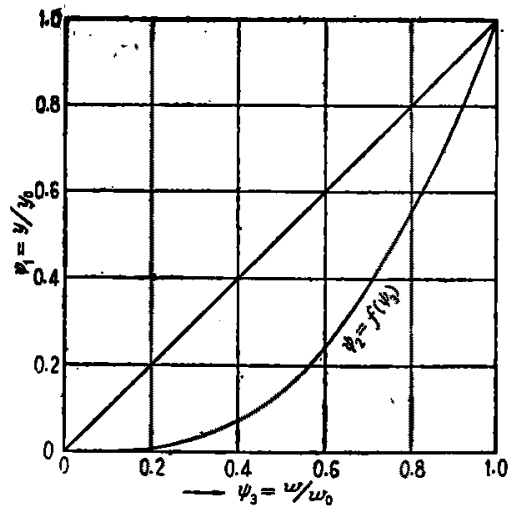

\begin{tabular}{lclllc}
\hline \multicolumn{7}{c}{ Table } & \multicolumn{1}{c}{$I$} \\
& \multicolumn{7}{c}{$f_{1}$} & $f_{1}-f_{1} / 4$ & $f_{1} / 2$ & $1 /(1-f)$ \\
\hline 0.05 & 0 & 0.05 & 0.0375 & 0.025 & 1 \\
0.1 & 0 & 0.1 & 0.075 & 0.05 & 1 \\
0.2 & 0 & 0.2 & 0.15 & 0.10 & 1 \\
0.3 & 0.025 & 0.275 & 0.2312 & 0.1375 & 1.024 \\
0.4 & 0.075 & 0.325 & 0.3187 & 0.1625 & 1.08 \\
0.5 & 0.155 & 0.345 & 0.4138 & 0.1725 & 1.18 \\
0.6 & 0.260 & 0.340 & 0.5150 & 0.1700 & 1.35 \\
0.7 & 0.390 & 0.310 & 0.6225 & 0.1550 & 1.637 \\
0.8 & 0.545 & 0.255 & 0.7368 & 0.1275 & 2.2 \\
0.9 & 0.745 & 0.155 & 0.8612 & 0.0775 & 3.92 \\
0.95 & 0.870 & 0.075 & 0.9312 & 0.0375 & 7.70 \\
& & & & & \\
\hline
\end{tabular}

Fig. 1

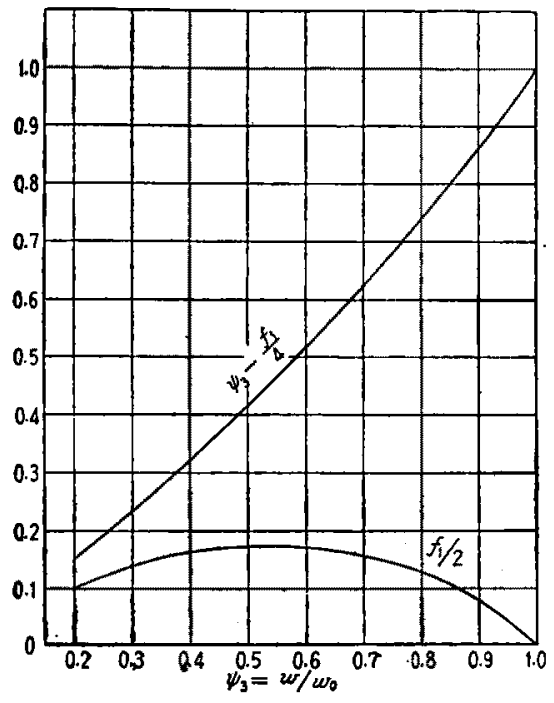

F:g. 2

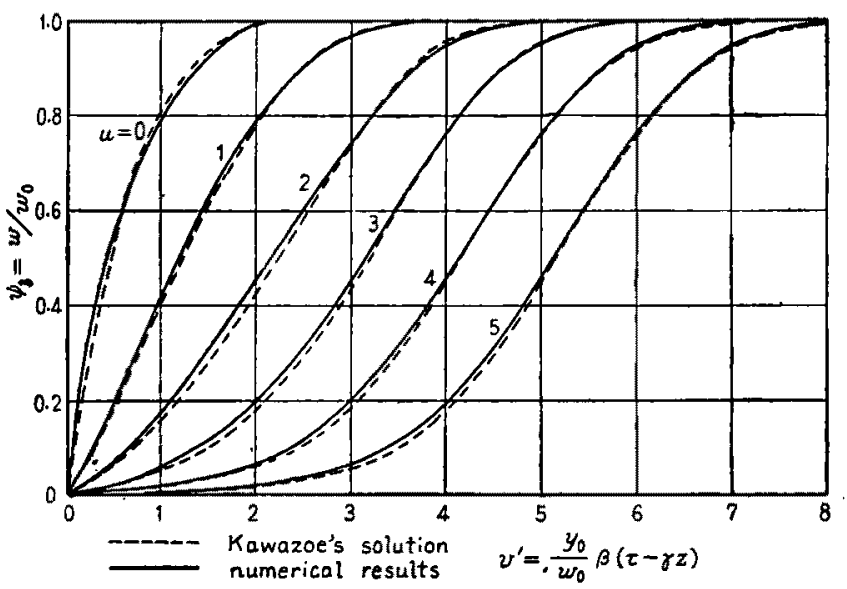

Fig, $\quad 3$

あ忿りまた割合に複雅である。筆者は精度ならびに計算 の容易さをる考虑にいれて数值解に上る新しい解法を提 案した。

\section{Nomenclatures}

$F_{\text {. }}$ : external void fraction of bed

$G$ : mass velocity of adsorbate-free fluid

$\left[\mathrm{kg} / \mathrm{m}^{2} \mathrm{hr}\right]$

$H_{d}:$ over-all heights of mass transfer units

$w$ : adsorbate content of solid [ $\mathrm{kg} / \mathrm{kg}$ solid]

$w_{0}$ : mass of adsorbate per unit mass of adsorbent in equilibrium with the entering gas

$[\mathrm{kg} / \mathrm{kg}]$

$y$ : adsorbate contente of fluid stream

[kg/kg fluid]

$y^{*}$ : equilibrium adsorbate content of the fluid stream

[kg/kg fluid]

$y_{0}$ : mass of adsorbate per unit mass of adsorbate-free gas in the extering stream

[kg/kg fluid]

$z$ : distance in bed measured in direction of flow

[m]

T: time

[hr]

$\rho_{B}:$ bulk density of bed

$\left[\mathrm{kg} / \mathrm{m}^{3}\right]$

$\rho_{G}:$ density of gas

\section{Literature cited}

1) L. V. Grossman: Trans. Amer. Inst. Chem. Engrs., 42, 535 (1946)

2) O. A. Hougen: Chem. Process. Principles vol. III, p. 1094 (1950)

3) K. Kawazoe: Advanced Chem. Eng., p. 94 97 (1950)

4) S. Sugiyama, Chem. Eng. (Japan), 22, 771 (1958) 


\section{Isothermal Adsorption with Complex Equilibrium}

\section{S. Sugiyama*}

Where the relationship between the equilibrium adsorbate content of the adsorbent and that of the gas was not linear, the differential equation for unsteady state adsorption was solved by numerical calculation and the method was compared with the graphical one.

* Department of Chemical Engineering, Nagoya University

\section{噴露乾燥に関する諸問題}

昨年 11 月の座歌会（本号“協会の動” 橍参照)は意外に反響を呼んだようである。 そこでこの問題に関し少し紙面をいたたくこ そにしたい。

まず嘪雾方法つまり液の微粒化という問題 については，回転网校型，加止ノズル型ある いは2 流体ノズル型, そのいずれにしても。 すでに相当研究が進んで括り，処理すへき溶 夜や证獎の性状，量，製品粒度（見挂密度） などが与えられれば，それに適した方法を選 らことはそれほどすすかしいことではない。 これに对して乾燥器の型式，すなかち堅型 (円筒型，サイクロン型) か横型か，また熱 ガスと液滴との相対運動が並流, 向流, 複合 流のいずれの型式に属し、いかなるフローハ タンを示すかといろ問题は，液滴の蒸発した がってまた製品の乾燥状態, 警奻浑, 器壁へ の付着の問題などすべてに深く関俰し，もっ とも複雑で厄介な問題でする。結局は処理 液，製品の両面から適切な型式を䅅験的に決 定しているのが実情のよ5である。

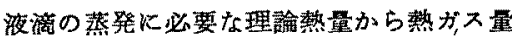
を求めることは計算上は容易であるが，問題 はこのさい用いる熱效率の数值にある。同様 に熱ガスと液滴との平均接鳋時間，したがっ てまた乾燥室の大さ（液滴の飛翔距離とも関 俰）などの波定す全く経験に上っている。没 涪 1 個についての乾燥典線を求めることも基
礎実駼として行われているが，対象になるの は波滴群だから，設計に役立たせるたはなお 多くの年月を要するであろ5。また1個の液 滴を崩さずに保っていく実験技術そのるの にもかなりの問題が垡されているよ5に思ら (ことに製品が中空球の場合など)。 液滴の乾燃が十分ならば器壁への付等の問 題は起らないはずであるが，事実はそうでな く，熱的に不安定なるのを报らだけに問題は 大きい。これを避けるには，器壁その他がク トなど面をできるだけ滑らかにすること (フルミよりすステンレス, Kel-F ライニン タ゚など，原液に邀当な界面活性郕を湿入す ること，あるいは蛋取機や電磁振動㙨を用い るなど，の方法が採られているが，るちろん 第一の方法がもっともよい。

最後にスタールフップの点に一眉しておこ 5。処理量の大小に肳らず，液滴の大さと乙 てはある範用内の粹度を示すことが必要であ る。いいかえれば夜滴の大さについては緦対 值そのものが重要である。ここにスケールフ ップについての閣題点がひそスでいる。実娩 室的な小型のあのではあまり効果はなく，あ る程度大きな乾焻器についてのデータてなけ れば，スケールアップに利用することはもず かていであろ5。(サイクロンその他の付属

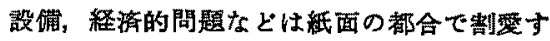
๖)

(S) 